nature international journal of obesity articles article

Search E-alert Submit Login

Article | Published: 19 December 2018

Pediatrics

\title{
Comparison of salivary proteome of children with different sensitivities for bitter and sweet tastes: association with body mass index
}

Lénia Rodrigues, Rosa Espanca, Ana Rodrigues Costa, Célia Miguel Antunes, Clarinda Pomar, Fernando Capela-Silva, Cristina Conceição Pinheiro, Pedro Domingues, Francisco Amado $\square$ \& Elsa Lamy $\square$ International Journal of Obesity 43, 701-712(2019) $\mathbf{5 0 7}$ Accesses | $\mathbf{4}$ Citations | $\mathbf{5}$ Altmetric| Metrics

\section{Abstract}

\section{Background/objectives}

Oral sensorial perception is a key aspect in food choices and knowing the mechanisms modulating such perception is of major importance in the context of child obesity, which is reaching high rates in Mediterranean countries. Salivary proteome has been linked to taste sensitivity in adults. The aim of this 
study was to search for differences in salivary proteomes of children with different bitter or sweet taste sensitivities and to assess if these potential differences are associated with their body mass index percentile (BMI percentile).

\section{Subjects/methods}

387 children aged 8-9 years old were assessed for BMI percentile and classified according to their sensitivity to bitter and sweet tastes, according to their caffeine and sucrose detection thresholds, respectively. Saliva protein composition was compared among taste sensitivity groups, taking into account BMI percentile and gender, using gel-based proteomics approaches, coupled to mass spectrometry for protein identification.

\section{Results}

Among the salivary proteins related to bitter taste sensitivity, higher levels of cystatins were observed in bitter-sensitive children, in the case of those of normal weight, and in bitter low-sensitive, in the case of overweight children. For sweetness, the relationship between saliva and taste perception was also dependent on BMI percentile, with several proteins (including salivary cystatins) differing between taste sensitivity groups, with 
disparities arising between normal-weight and overweight children. Cystatin isoforms A, $B$ and SA were observed to be considerably increased in saliva from obese children.

\section{Conclusions}

Salivary proteome is related with sensitivities to bitter and sweet tastes in children, but the association is dependent on BMI percentile and gender.

\section{Access options}

Subscribe to Journal

Get full journal access for 1 year

\section{$585,29 €$}

only $48,77 €$ per issue

Subscribe

All prices include VAT for Portugal.

\section{Rent or Buy article}

Get time limited or full article access on

ReadCube. 


\section{Additional access options:}

$\log$ in

Access through your institution

Learn about institutional subscriptions

\section{References}

1. 1. Wijnhoven TM, Van Raaij JM, Spinelli A, Starc G, Hassapidou M, Spiroski I et al. WHO European Childhood Obesity

Surveillance Initiative: body mass index and level of overweight among 6-9-yearold children from school year 2007/2008 to school year 2009/2010. BMC Public Health. 2014. https://doi.org/10.1186/1471-2458-14806.

2. 2. WHO. Downward trend in overweight and obesity among Portuguese school children. 2018. http://www.euro.who.int/en/healthtopics/diseaseprevention/nutrition/news/news/2018/ 2/downward-trend-in-overweight-andobesity-among-portuguese-schoolchildren (accessed 12 Jun2018).

3. 3. Lamy E, Pinheiro C, Rodrigues L, Capela e Silva F, Lopes OS, Tavares S et al. 
Determinants of tannin-rich food and beverage consumption: Oral perception vs. psychosocial aspects. 2016.

4. 4. Drewnowski A, Gomez-Carneros C Bitter taste, phytonutrients, and the consumer: A review. Am. J. Clin. Nutr. 2000. https://doi.org/10.1111/j.17503841.2011.02471.x.

5. 5. Bell KI, Tepper BJ. Short-term vegetable intake by young children classified by 6 -n-propylthoiuracil bittertaste phenotype. Am. J. Clin. Nutr. 2006;245-51.

6. 6. Keller KL, Adise S. Variation in the ability to taste bitter thiourea compounds: implications for food acceptance, dietary intake, and obesity risk in children. Annu Rev Nutr 2016. https://doi.org/10.1146/annurev-nutr071715-050916.

7. 7. Kildegaard H, Tønning E, Thybo AK. Preference, liking and wanting for beverages in children aged 9-14years: role of sourness perception, chemical composition and background variables. Food Qual Prefer 2011. 
https://doi.org/10.1016/j.foodqual.2011.0 3.005 .

8. 8. Joseph PV, Reed DR, Mennella JA. Individual differences among children in sucrose detection thresholds: relationship with age, gender, and bitter taste genotype. Nurs Res 2016. https://doi.org/10.1097/NNR.000000000 0000138.

9. 9. Barbarossa IT, Melis M, Mattes MZ, Calò C, Muroni P, Crnjar R, et al. The gustin (CA6) gene polymorphism, rs2274333 (A/G), is associated with fungiform papilla density, whereas PROP bitterness is mostly due to TAS2R38 in an ethnically-mixed population. Physiol Behav. 2015;138:6-12.

10. 10. Dsamou M, Palicki O, Septier C, Chabanet C, Lucchi G, Ducoroy P, et al. Salivary protein profiles and sensitivity to the bitter taste of caffeine. Chem Senses. 2012;37:87-95.

11. 11. Cabras T, Melis M, Castagnola M, Padiglia A, Tepper BJ, Messana I, et al. Responsiveness to 6-n-propylthiouracil (PROP) is associated with salivary levels of two specific basic proline-rich 
proteins in humans. PLOS ONE. 2012;7:e30962.

12. 12. Rodrigues L, da Costa G, Cordeiro C, Pinheiro CC, Amado F, Lamy E. Relationship between saliva protein composition and 6-n-Propylthiouracil bitter taste responsiveness in young adults. J Sens Stud. 2017; 32. https://doi.org/10.1111/joss.12275.

13. 13. Rodrigues L, Costa G, Cordeiro C, Pinheiro C, Amado F, Lamy E. Salivary proteome and glucose levels are related with sweet taste sensitivity in young adults. Food Nutr Res. 2017;61:1389208.

14. 14. Stolle T, Grondinger F, Dunkel A, Meng C, Médard G, Kuster B et al. Salivary Proteome Patterns Affecting Human Salt Taste Sensitivity. J Agric Food Chem. 2017. https://doi.org/10.1021/acs.jafc.7b03862.

15. 15. Morzel M, Chabanet C, Schwartz C, Lucchi G, Ducoroy P, Nicklaus S. Salivary protein profiles are linked to bitter taste acceptance in infants. Eur J Pediatr. 2014;173:575-82.

16. 16. Rodrigues L, Espanca R, Costa AR, Antunes CM, Pomar C, Capela-Silva F et 
al. Association between salivary leptin levels and taste perception in children. J Nutr Metab 2017; 2017. https://doi.org/10.1155/2017/7260169.

17. 17. Tepper BJ, Melis M, Koelliker Y, Gasparini P, Ahijevych KL, Barbarossa IT. Factors influencing the phenotypic characterization of the oral marker, PROP. Nutrients. 2017. https://doi.org/10.3390/nu9121275.

18. 18. Lamy E, Simões C, Rodrigues L, Costa AR, Vitorino R, Amado F, et al. Changes in the salivary protein profile of morbidly obese women either previously subjected to bariatric surgery or not. J Physiol Biochem. 2015;71:691-702.

19. 19. LAEMMLI UK. Cleavage of structural proteins during the assembly of the head of bacteriophage T4. Nature. 1970;227:680-5.

20. 20. Rodrigues L, da Costa G, Cordeiro C, Pinheiro CC, Amado F, Lamy E. Relationship between saliva protein composition and 6- n-Propylthiouracil bitter taste responsiveness in young adults. J Sens Stud 2017: e12275. 
21. 21. Rodrigues L, Mouta $R$, Costa $A R$, Pereira A, Capela e Silva F, Amado F, et al. Effects of high fat diet on salivary $\alpha-$ amylase, serum parameters and food consumption in rats. Arch Oral Biol. 2015;60:854-62.

22. 22. Pallaro A, Barbeito $S$, Taberner $P$, Marino P, Franchello A, Strasnoy I, et al. Total salivary IgA, serum C3c and IgA in obese school children. J Nutr Biochem. 2002;13:539-42.

23. 23. Baron AC, DeCarlo AA, Featherstone JDB. Functional aspects of the human salivary cystatins in the oral environment. Oral Dis 1999. https://doi.org/10.1111/j.16010825.1999.tb00307.x.

24. 24. Lafarge JC, Naour N, Clément K, Guerre-Millo M. Cathepsins and cystatin $\mathrm{C}$ in atherosclerosis and obesity. Biochimie. 2010. https://doi.org/10.1016/j.biochi.2010.04.0 11.

25. 25. Yang M, Sun J, Zhang T, Liu J, Zhang J, Shi MA et al. Deficiency and inhibition of cathepsin $\mathrm{K}$ reduce body weight gain and increase glucose metabolism in mice. 
Arterioscler Thromb Vasc Biol 2008.

https://doi.org/10.1161/ATVBAHA.108.172 320.

26. 26. Wasen $\mathrm{E}$, Isoaho $\mathrm{R}$, Mattila $\mathrm{K}$, Vahlberg T, Kivela S-L, Irjala K. Serum cystatin $\mathrm{C}$ in the aged: relationships with health status. Am J Kidney Dis. 2003.

27. 27. Luc G, Bard JM, Lesueur C, Arveiler D, Evans A, Amouyel P et al. Plasma cystatin$\mathrm{C}$ and development of coronary heart disease: The PRIME Study. Atherosclerosis. 2006;375-80. https://doi.org/10.1016/j.atherosclerosis. 2005.06.017.

28. 28. Veerman EC, van den Keybus PA, Vissink A, Nieuw Amerongen AV. Human glandular salivas: their separate collection and analysis. Eur J Oral Sci. 1996;104:346-52.

29. 29. Dickinson DP. Salivary (SD-type) cystatins: over one billion years in the making-but to what purpose? Crit. Rev. Oral Biol. Med. 2002. https://doi.org/10.1177/1544111302013006 06.

30. 
30. Morzel M, Neyraud E, Brignot H, Ducoroy P, Jeannin A, Lucchi G et al. Multi-omics profiling reveals that eating difficulties developed consecutively to artificial nutrition in the neonatal period are associated to specific saliva composition. J Proteomics. 2015. https://doi.org/10.1016/j.jprot.2015.07.02 8.

31. 31. Shatzman AR, Henkin RI. Gustin concentration changes relative to salivary zinc and taste in humans. Proc Natl Acad Sci USA. 1981;78:3867-71.

32. 32. Henkin RI, Martin BM, Agarwal RP. Efficacy of exogenous oral zinc in treatment of patients with carbonic anhydrase VI deficiency. Am J Med Sci. 1999. https://doi.org/10.1097/00000441199912000-00006.

33. 33. Feeney EL, Hayes JE. Exploring associations between taste perception, oral anatomy and polymorphisms in the carbonic anhydrase (gustin) gene CA6. Physiol Behav. 2014;128:148-54.

34. 34. Sivakumar T, Hand AR, Mednieks M. Secretory proteins in the saliva of 
children. J Oral Sci. 2009.

https://doi.org/10.2334/josnusd.51.573.

35. 35. Yang ZM, Chen LH, Zhang M, Lin J, Zhang J, Chen WW et al. Age differences of salivary alpha-amylase levels of basal and acute responses to citric acid stimulation between chinese children and adults. Front Physiol. 2015. https://doi.org/10.3389/fphys.2015.0034 0.

36. 36. James CE, Laing DG, Oram N. A comparison of the ability of 8-9-Year-old children and adults to detect taste stimuli. Physiol Behav. 1997. https://doi.org/10.1016/S00319384(97)00030-9.

37. 37. Lorenz K, Bader M, Klaus A, Weiss W, Görg A, Hofmann T. Orosensory stimulation effects on human saliva proteome. J Agric Food Chem. 2011. https://doi.org/10.1021/jf2024352.

38. 38. Santos JL, Saus E, Smalley SV, Cataldo LR, Alberti G, Parada J, et al. Copy number polymorphism of the salivary amylase gene: implications in human nutrition research. J Nutr Nutr. 2012;5:117-31. 
39. 39. Lima DP, Diniz DG, Moimaz SAS, Sumida DH, Okamoto AC. Saliva: reflection of the body. Int J Infect Dis. 2010;14:e184-e188.

40. 40. Butchibabu K, Kiran K, Koppolu P, Kumar S, Muralikrishna T, Swaminathan M. Estimation of salivary immunoglobulin A levels in gingivitis and chronic periodontitis patients before and after phase I periodontal therapy. J Dr NTR Univ Heal Sci. 2014;3:23.

\section{Acknowledgements}

This paper was supported by national funding from the Portuguese Science Foundation (FCT) under the project UID/AGR/00115/2013 (ICAAM - University of Évora). The authors also acknowledge financial support from FCT in the form of Elsa Lamy's FCT investigator contract IF/01778/2013. FCT played no role in the development of this work or in its submission for publication.

\section{Author information}

\section{Affiliations}


1. Institute of Mediterranean Agricultural and Environmental Sciences (ICAAM), University of Évora, Évora, Portugal

Lénia Rodrigues \& Elsa Lamy

2. Grouping of Health Centres of Central Alentejo (ACES, AC), Évora, Portugal Rosa Espanca

3. Institute of Earth Sciences (ICT), Institute of Mediterranean Agricultural and Environmental Sciences (ICAAM) and Department of Chemistry, University of Évora, Évora, Portugal Ana Rodrigues Costa \& Célia Miguel Antunes

4. Centre of Research in Education and Psychology (CIEP) and Department of Pedagogy and Education, University of Évora, Évora, Portugal

Clarinda Pomar

5. Institute of Mediterranean Agricultural and Environmental Sciences (ICAAM) and Department of Biology, University of Évora, Évora, Portugal 
6. Institute of Mediterranean Agricultural and Environmental Sciences (ICAAM) and Department of Zootechnics, University of Évora, Évora, Portugal

Cristina Conceição Pinheiro

7. Organic Chemistry, Natural and Agrofood Products (QOPNA) and Department of Chemistry, University of Aveiro, Aveiro, Portugal Pedro Domingues \& Francisco Amado

\section{Corresponding authors}

Correspondence to Francisco Amado or Elsa Lamy.

\section{Ethics declarations}

\section{Conflict of interest}

The authors declare that they have no conflict of interest. 


\section{Additional information}

Publisher's note: Springer Nature remains neutral with regard to jurisdictional claims in published maps and institutional affiliations.

\section{Supplementary information}

Supplementary Figure 1 - legend

Supplementary Table 1

Supplementary Table 2

Supplementary Table 3

Supplementary Table 4

Supplementary Table 5

Supplementary Table 6

Supplementary Figure 1

\section{Rights and permissions}

Reprints and Permissions

\section{About this article}

Cite this article

Rodrigues, L., Espanca, R., Costa, A.R. et al.

Comparison of salivary proteome of children

with different sensitivities for bitter and sweet tastes: association with body mass index. Int J 
Obes 43, 701-712 (2019).

https://doi.org/10.1038/s41366-018-0289-5

Received08 March 2018

Revised17 October 2018

Accepted19 November 2018

Published19 December 2018

Issue DateApril 2019

DOIhttps://doi.org/10.1038/s41366-018-

0289-5

Subjects Proteins $\bullet$ Risk factors

\section{Further reading}

- Changes in Salivary Proteome in Response to Bread Odour

Laura Carreira, Paula Midori Castelo[...] \& Elsa

Lamy

Nutrients (2020) 
- Saliva as a non-invasive tool for assessment of metabolic and inflammatory biomarkers in children

Asta Tvarijonaviciute, Nuria Martinez-

Lozano[...] \& Jose J. Cerón

Clinical Nutrition (2019)

International Journal of Obesity

ISSN 1476-5497 (online)

\section{nature research}

\section{SPRINGER NATURE}

(C) 2020 Springer Nature Limited 